\title{
MOSQUITO CONTROL IN MASSACHUSETTS ${ }^{1}$
}

\section{By GeORge S. Tulloch}

Previous to 1929 little attention had been given to the control of mosquitoes in Massachusetts. Various municipalities through their local boards of health had inaugurated campaigns for the control of the common house mosquito, Culex pipiens, and in a few instances communities along the sea coast had directed some attention to the control of the salt marsh mosquito Aëdes solicitans.

In 1911, through the efforts of a group of citizens of Ipswich, on the North Shore of Massachusetts, the ditching of a large area of salt marsh practically eliminated breeding pools in that particular region. Since the area ditched was only a small portion of a large salt marsh, the benefit derived was of little value, as the extensive flight range of Aëdes sollicitans permitted infestation from adjacent areas. However, the permanence and practicability of mosquito control by ditching was clearly shown by this project, for the ditches are still functioning properly, and that section of the marsh is in nearly a non-breeding condition after nineteen years of periodical flushing by the high course tides.

In 1929 the State of Massachusetts through its Reclamation Board took an active interest in the problem of mosquito control. This Board, comprised of three men, acting in an advisory capacity, cooperated with various towns in the salt marsh areas and suggested control measures. Under the State Reclamation Board groups of cities and towns are authorized to cooperate by forming a mosquito control project directed by commissioners appointed by

${ }^{1}$ Given before the Entomological Society of America at the Case School of Applied Science, Cleveland, Ohio, December 30, 1930. 
the board. Money appropriated by the members of the project can then be spent for the benefit of the project as a whole, without being restricted by town or city boundaries. Adopting this method money was available for actual ditching operations early in 1930.

The island of Nantucket was the first to start operations in April. This island, covering approximately fifty square miles, is situated twenty miles from the southern coast of Cape Cod and about twelve miles from its neighbor, Martha's Vineyard. Its isolated position outside the normal flight range of Aëdes sollicitans (the prevalent mainland mosquito) made it an ideal spot to demonstrate the practicability of mosquito control by ditching. The area of salt marsh on the island was 838 acres, while fresh water swamps included over 1300 acres. The salt marsh area was treated first, and over 300,000 feet of ditches, ten inches wide and 24 inches deep, were constructed before it was considered to be in a non-breeding condition. Then attention was directed to the fresh water areas. Here the topography of the island did not permit the accomplishment of mosquito control by the simple means of ditching. In some cases culverts and underground drains were constructed and in a few instances it was necessary to resort to oiling, but in general, whenever possible, permanent control measures were effected. The presence of Mansonia perturbans, the larva of which attaches itself to roots and stems of aquatic plants, added to the problem, since it only can be controlled by completely removing the water, a method which oftentimes is impracticable.

The control measures carried on at Nantucket have reduced mosquitoes and added much to the comfort of the residents. In addition land values in some regions have increased twofold or more.

The success of the Nantucket project encouraged the Cape Cod Chamber of Commerce to inaugurate a drive to raise funds to carry on the control work on a more extensive basis than that provided for by local appropriations. Two hundred thousand dollars were pledged by public subscription, the money to be spent over a period of three 
years, seventy thousand dollars of which became available in August, 1930. Extensive operations were started immediately, and at the present time over 1,000,000 feet of ditches have been dug and the worst breeding areas eliminated. By May, 1931, it is estimated that an additional 500,000 feet will be completed.

In addition to these projects the State of Massachusetts through its Department of Public Works has built a dike, 3,000 feet long and about five feet high, across Race Run at Provincetown, on the tip of Cape Cod. This dike now prevents the tide waters from reaching an area six hundred acres in extent, formerly known to be a prolific breedingplace of salt marsh mosquito. The cost of construction of this dike was assumed by the State, being on land owned by the Commonwealth. In this case, through its Department of Public Works, and also through its Reclamation Board, the State of Massachusetts again has shown her foresight in taking advance steps toward the comfort and prosperity of her citizens. 

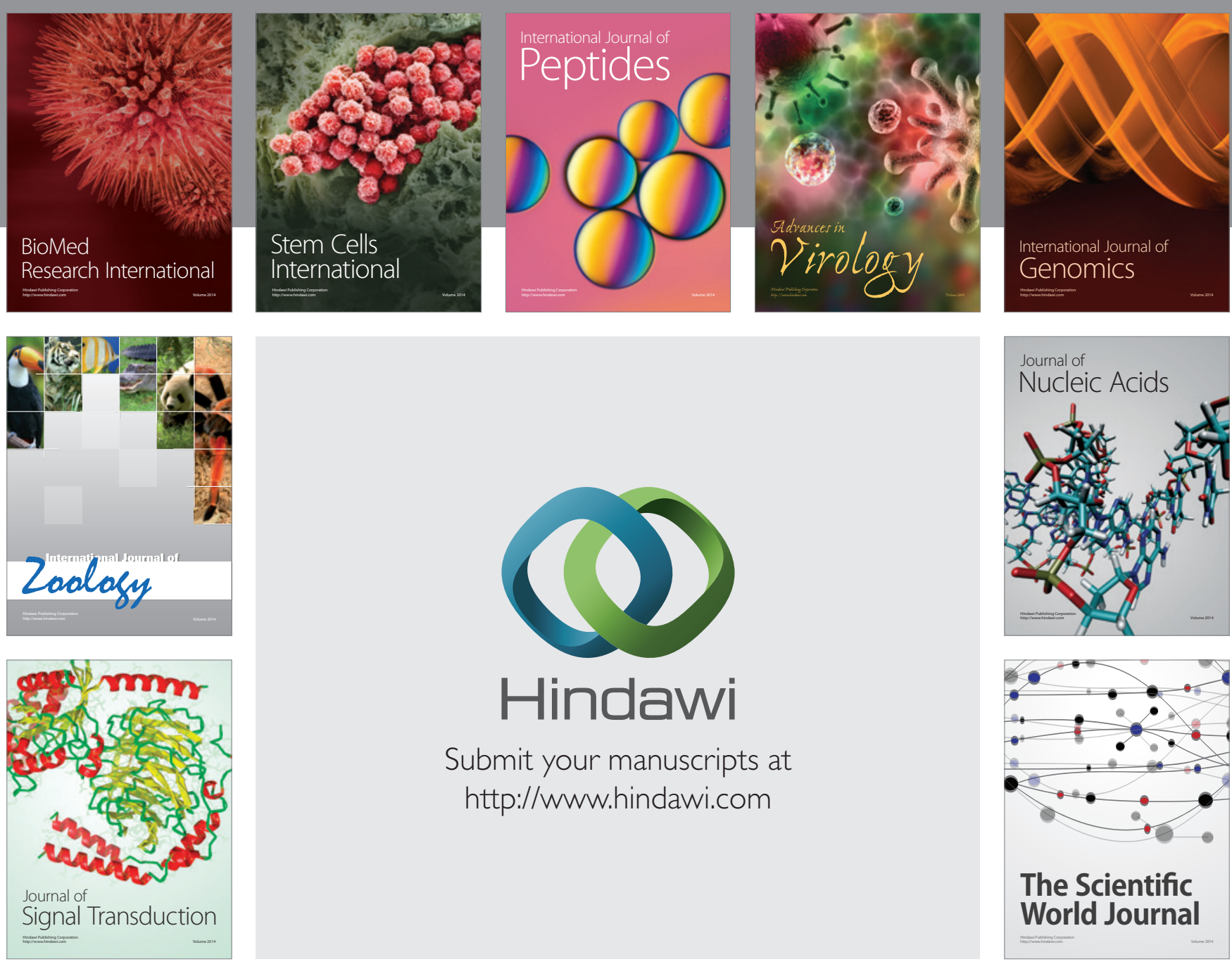

Submit your manuscripts at

http://www.hindawi.com
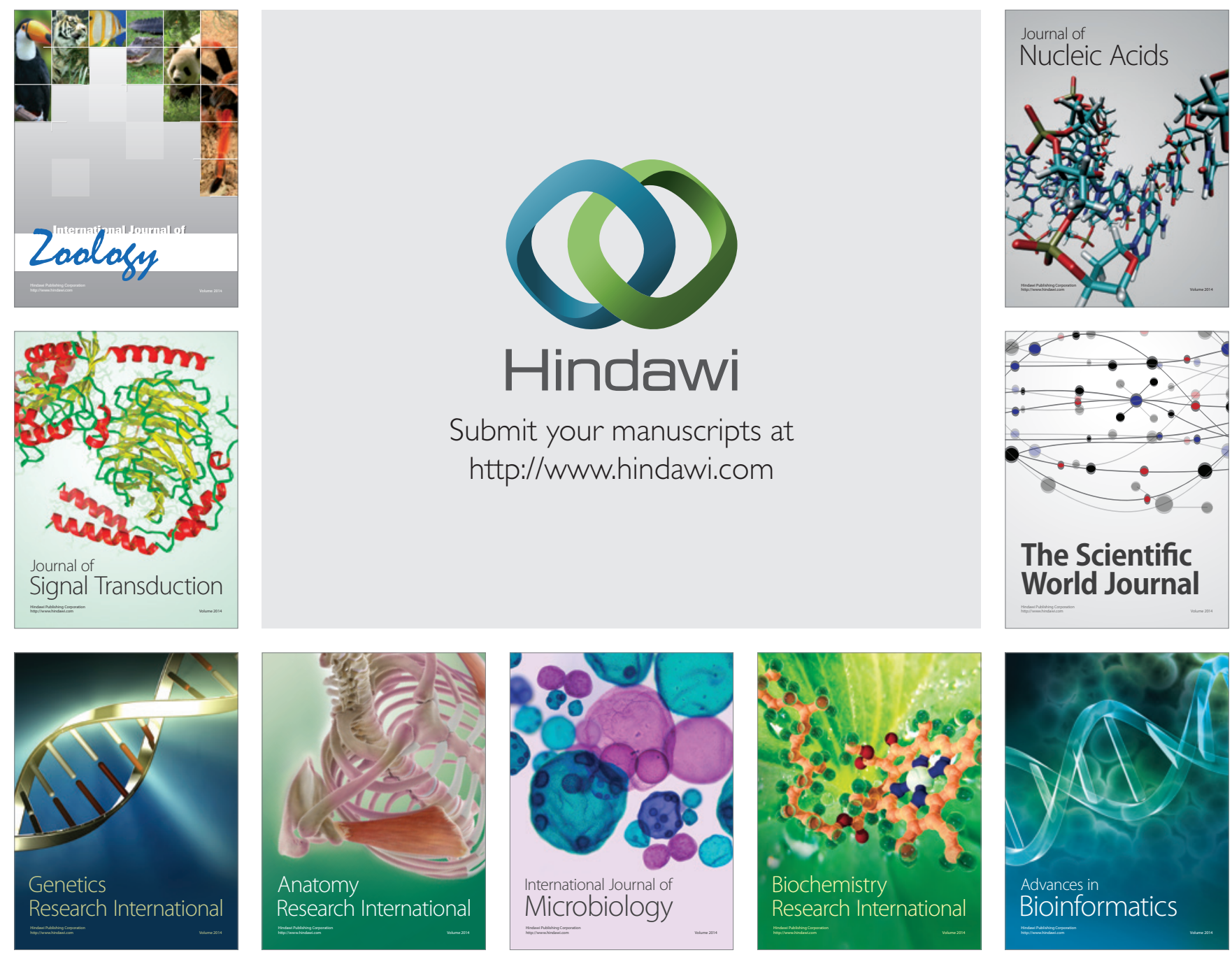

The Scientific World Journal
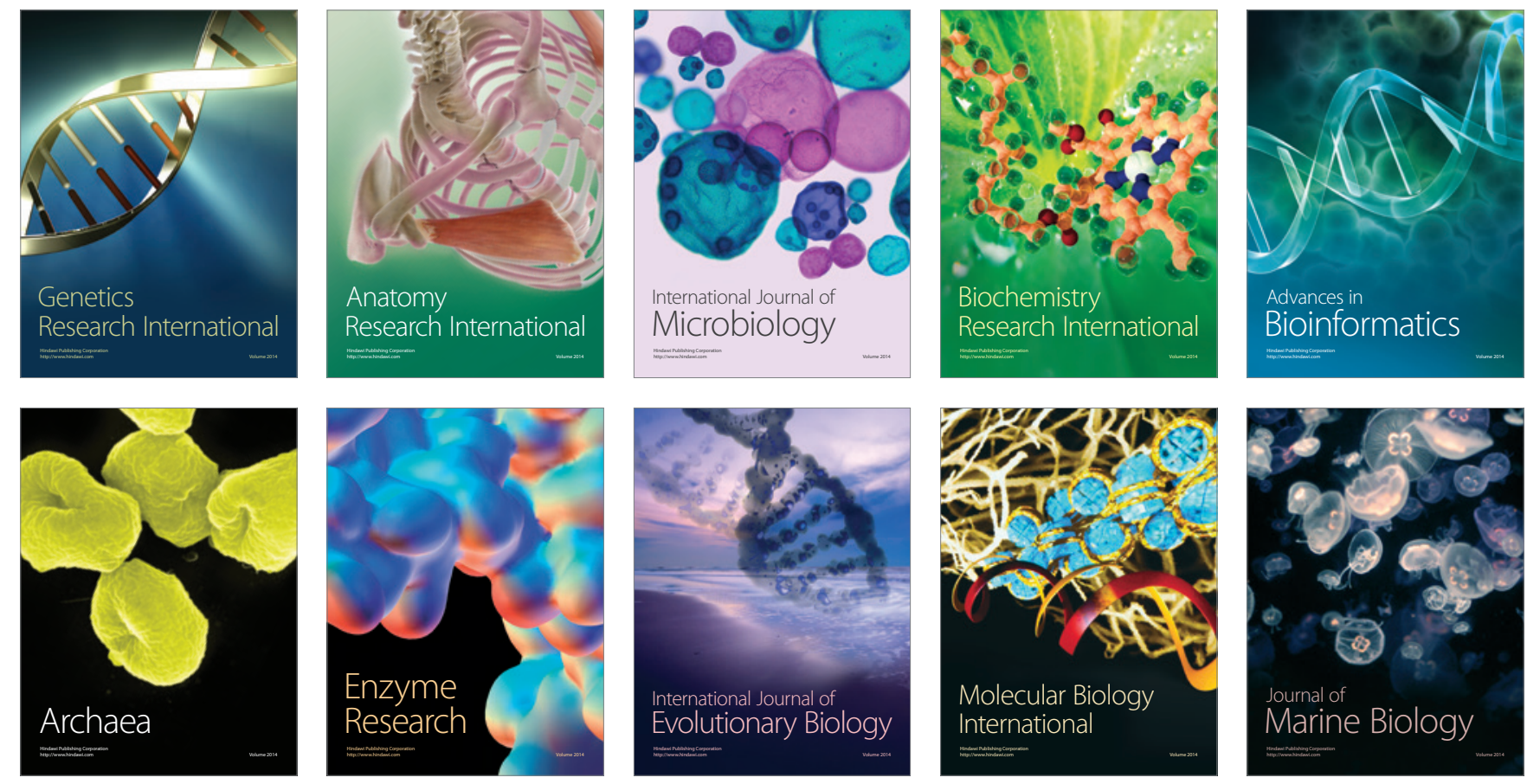